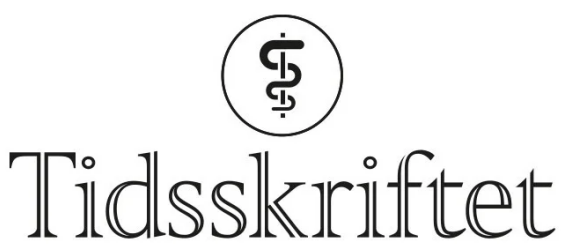

DEN NORSKE LEGEFORENING

\title{
En immunsupprimert kvinne i 70- årene med nattesvette og vekttap
}

NOE Å LARE AV

\section{JAN SVENDSEN}

jan.svendsen@vestreviken.no

Medisinsk avdeling

Vestre Viken, Bærum sykehus

Jan Svendsen er spesialist i indremedisin og infeksjonssykdommer og overlege.

Forfatteren har fylt ut ICMJE-skjemaet og oppgir ingen interessekonflikter.

\section{ANDERS AUNE TVEITA}

Medisinsk avdeling

Vestre Viken, Bærum sykehus

Anders Aune Tveita er ph.d., forsker og lege i spesialisering.

Forfatteren har fylt ut ICMJE-skjemaet og oppgir ingen interessekonflikter.

\section{ELLEN ABRY}

Medisinsk avdeling

Vestre Viken, Bærum sykehus

Ellen Abry er lege i spesialisering.

Forfatteren har fylt ut ICMJE-skjemaet og oppgir ingen interessekonflikter.

\section{ANNE ELISABETH TONAY CARLSEN}

Medisinsk avdeling

Vestre Viken, Drammen sykehus

Anne Elisabeth Tonay Carlsen er spesialist i indremedisin og overlege.

Forfatteren har fylt ut ICMJE-skjemaet og oppgir ingen interessekonflikter.

\section{KRISTIN BREKKE}

Medisinsk avdeling

Vestre Viken, Bærum sykehus

Kristin Brekke er ph.d., spesialist i indremedisin og infeksjonssykdommer og overlege.

Forfatteren har fylt ut ICMJE-skjemaet og oppgir ingen interessekonflikter.

\section{ELSE JOHANNE RØNNING}

Medisinsk avdeling

Vestre Viken, Bærum sykehus

Else Johanne Rønning er spesialist i indremedisin og infeksjonssykdommer og seksjonsoverlege.

Forfatteren har fylt ut ICMJE-skjemaet og oppgir ingen interessekonflikter. 


\section{Nattesvette og vekttap kan være alvorlige, men uspesifikke symptomer. Vi beskriver her en pasienthistorie der mange differensialdiagnoser ble vurdert før tverrfaglig tilnærming ledet til riktig diagnose.}

En kvinne i 7o-årene ble henvist til medisinsk poliklinikk på grunn av mistanke om kreft. Hun hadde på det tidspunktet hatt nattesvette i cirka fire måneder og et ufrivillig vekttap på 3 kilo over samme periode. Fra tidligere hadde hun revmatoid artritt, som var behandlet med rituksimab i cirka ti år. Ved første konsultasjon viste klinisk undersøkelse normale funn. Allmenntilstanden var god, og kvinnen hadde ikke feber. Blodprøver inkludert tyreoideahormoner var normale, bortsett fra lett forhøyet CRP på $22 \mathrm{mg} / \mathrm{L}$ (referanseområde o-5) og forhøyet ferritin på 9o6 $\mu \mathrm{g} / \mathrm{L}\left(\right.$ 15-20o $^{2}$ ). Transferrinmetning var normal. Test for hiv-antigen/antistoff var negativ.

Nattesvette kan ses ved kreftsykdom, spesielt lymfomer. Andre mulige årsaker er medikamentbivirkninger, endokrine sykdommer og enkelte infeksjonssykdommer. Pasienten hadde brukt rituksimab over mange år, og nattesvetten kunne derfor neppe forklares av dette alene. Hun brukte ingen andre medikamenter. Fravær av øvrige symptomer, kliniske funn og større biokjemiske avvik gjorde at man ikke utredet videre med tanke på endokrinologisk eller infeksiøs årsak.

Pasienten ble samme dag unders $ø$ kt med CT av thorax, abdomen og bekken. Denne viste normale forhold. Supplerende undersøkelser ble utført poliklinisk i løpet av de påfølgende åtte ukene. Mammografi med supplerende ultralyd var upåfallende. Ved koloskopi fjernet man en liten polypp som histologisk var godartet. Gastroskopi og gynekologisk undersøkelse avdekket ingen aktuell patologi.

Etter ovennevnte undersøkelser var mistanken om kreftsykdom betydelig svekket. Pasienten var fortsatt i god allmenntilstand og hadde ingen sykdomsfølelse. Man bestemte seg for å la fastlegen observere tilstanden videre. Grunnet videre vektnedgang ble pasienten et par måneder senere henvist til fornyet vurdering.

Ved konsultasjon cirka åtte måneder etter symptomdebut kunne pasienten fortelle om ytterligere vekttap ( 7 kilo til sammen). Hun hadde nå daglig feber opp mot $38,5{ }^{\circ} \mathrm{C}$ og allmenn sykdomsfølelse. Klinisk organunders $\emptyset$ kelse var fortsatt normal. Blodprøver viste normocytcr anemi med hemoglobin 9,6 g/dL (11,7-15,3), lett stigende CRP til $32 \mathrm{mg} / \mathrm{L}$ og ferritin $1132 \mu \mathrm{g} /$ L. Blodkultur var uten vekst. Tester for antinuklecere antistoffer (ANA) og antinøytrofile cytoplasmatiske antistoffer (ANCA) var negative. CT av thorax, abdomen og bekken ble gjentatt og viste økende miltstørrelse til $19 \mathrm{~cm}$ med noe heterogen kontrastopplading i miltparenkymet.

Nattesvette, vekttap, feber og forstørret milt med heterogen kontrastopplading gjorde at man nå mistenkte lymfom i milten. Metastaser til milt fra annen kreftsykdom virket mindre sannsynlig gitt den omfattende utredningen som allerede var gjort. Endokarditt virket lite sannsynlig med negativ blodkultur. Andre mulige infeksiøse årsaker ble ikke vurdert på dette tidspunktet.

Miltbiopsi ble utført uten komplikasjoner under kortvarig innleggelse tre dager etter konsultasjonen. Histologisk unders $ø$ kelse viste ekstramedullcr hematopoese og T-celle-hyperplasi av usikker årsak. Det var ikke holdepunkter for lymfom, og det ble heller ikke sett granulomer.

Ekstramedullær hematopoese kan ses ved flere tilstander, blant annet ved myelofibrose og kroniske anemier som talassemi og hemolytisk anemi. Da endelig svar på miltbiopsi forelå etter to uker, var hemoglobinkonsentrasjonen falt ytterligere til 8,9 g/dL. Differensialtelling av leukocytter viste normale verdier, men trombocyttkonsentrasjonen var lett redusert til $140 \times 10^{9} / \mathrm{L}\left(145^{-390} \times 10^{9}\right)$. Det var ikke tegn til hemolyse. CRP var fortsatt lett forhøyet på $35 \mathrm{mg} / \mathrm{L}$. Myeloproliferativ neoplasi som myelofibrose og myelodysplastisk syndrom framstod som mulige diagnoser, hvor særlig førstnevnte kan gi symptomer som feber, nattesvette og vekttap. Pasienten ble henvist til hematolog. 
Ved konsultasjon på hematologisk poliklinikk kom det frem at symptomene oppstod tre-fire uker etter et ferieopphold $i$ et vesteuropeisk land. Pasienten hadde vart på rundreise $i$ Asia et par år tidligere og var ofte på familiens landsted $i$ et nordisk land. Blod- og benmargsutstryk, benmargsbiopsi, veskestrømscytometri av blod og benmarg samt cytogenetiske og molekylcrpatologiske undersøkelser av benmarg gav ingen holdepunkter for lymfom eller annen hematologisk sykdom. Grunnet reiseanamnesen ble visceral leishmaniasis vurdert som mulig årsak, men prøver av benmargsaspirat og blod var negative for Leishmania-DNA. Prøve av benmargsaspirat var også negativ for Mycobacterium tuberculosis-kompleks-DNA. Man stod så langt uten diagnose. Pasientens symptomer var økende, med daglige frostanfall, progredierende vekttap og forverring av allmenntilstanden. PET-CT ble bestilt, og pasienten ble henvist til infeksjonsmedisinsk poliklinikk. Det var nå gått ni måneder siden symptomdebut.

Pasienten hadde fortsatt nattesvette, og totalt vekttap var nå 10 kilo. Hun beskrev daglige episoder med kraftige frostanfall og feber opptil $39^{\circ} \mathrm{C}$, og i tillegg var det tilkommet tørrhoste.

Allmenntilstanden var klart redusert. Orienterende blodprøver viste hemoglobin 8,4 g/dL, CRP $45 \mathrm{mg} / \mathrm{L}$, ferritin $1478 \mu \mathrm{g} / \mathrm{L}$ og albumin $29 \mathrm{~g} / \mathrm{L}$ (34-45). Røntgen thorax var normal. Poliklinisk infeksjonsmedisinsk utredning ble igangsatt.

Pasientens reiseanamnese gjorde at man måtte vurdere infeksiøse agens vi ikke har i Norge. Enkelte av disse, som Leishmania, kan ha lang inkubasjonstid.

Ved visceral leishmaniasis er feber, cytopenier og splenomegali vanlig. Imidlertid var test for Leishmania-DNA negativ i beinmargsaspirat og blod, slik at mistanken var svekket. Leishmania-DNA ble heller ikke påvist i resterende vevsbiter fra miltbiopsi, og serologisk analyse var negativ.

Endokarditt var fortsatt en mulighet, men også nye blodkulturer var uten vekst. Serologisk analyse for Coxiella burnetii var negativ. Ekkokardiografi utført én uke etter påbegynt infeksjonsutredning gav ikke holdepunkter for endokarditt.

Brucellose er en hyppig årsak til langvarig feber i middelhavslandene, men framstod lite sannsynlig med negative blodkulturer og negativ serologi.

Pasienten hadde et par år tidligere vært på rundreise i et asiatisk land. Inkubasjonstiden for Plasmodium falciparum er som regel kort, mens det er beskrevet tilfeller av Plasmodium vivax med meget lang inkubasjonstid. Selv om mistanken var liten, valgte vi å undersøke med malaria-antigentest, mikroskopi av tynn- og tykkdråpeutstryk og PCR-test for malaria, som alle var uten funn.

Babesiose ble vurdert, men var også lite sannsynlig i fravær av hemolyse og uten intraerytrocytære parasitter i blodutstryk. Babesia-DNA ble ikke påvist i blod.

Miliærtuberkulose kan gi et lignende sykdomsbilde, men da ville man forvente billeddiagnostiske funn i lunger. PET-CT-undersøkelse ble utført to dager etter første konsultasjon ved infeksjonspoliklinikken og viste ingen fokale infeksjons- eller malignitetssuspekte opptak.

Pasientens frostanfall gav mistanke om infeksjonssykdom med bakteriemi. Flere blodkulturer var imidlertid uten vekst. På bakgrunn av dette ble det fattet mistanke om bakteriemi forårsaket av intracellulære bakterier. Det forelå oppysninger om opphold i område med flått, men det var ingen erkjente flåttbitt. EDTA-fullblod ble sendt til Sørlandet sykehus Kristiansand for PCR-analyse med tanke på flåttbårne bakterier.

Ved telefonoppfølging fem dager senere kunne pasienten fortelle om ytterligere forverring av tilstanden. Hun var nå kontinuerlig febril med temperatur $38,5-39^{\circ} \mathrm{C}$ og ble innlagt for empirisk behandling med doksysyklin $100 \mathrm{mg} \times 2$ per os under observasjon. Ved innkomst var blodtrykket $120 / 68 \mathrm{~mm} \mathrm{Hg}$, pulsen $89 \mathrm{slag} / \mathrm{min}, \mathrm{SaO}_{2} 97 \%$, respirasjonsfrekvensen 20 pust/min og temperaturen $38,8^{\circ} \mathrm{C}$. Etter ett døgns behandling var pasienten feberfri. Matlysten kom tilbake, og allmenntilstanden bedret seg. To dager etter oppstart av doksysyklinbehandling ble vi informert per telefon om sterkt positiv PCR for Candidatus Neoehrlichia mikurensis. Pasienten ble utskrevet neste 
dag med videre behandling med doksysyklin $100 \mathrm{mg} \times 2$ per os i til sammen tre uker.Ved kontroll etter en ukes behandling var hun fortsatt feberfri, med avtagende nattesvette og allmenntilstand i fin bedring. Blodprøver viste økt hemoglobinkonsentrasjon på 10,9 g/dL og normalisert CRP. Det videre forløpet var ukomplisert. Ultralydkontroll cirka tre måneder senere viste normalisert miltstørrelse.

\section{Diskusjon}

Candidatus Neoehrlichia mikurensis ble først beskrevet som humanpatogen i 2010 (1-3). Det er en flåttbåren, intracellulær bakterie i familien Anaplasmataceae, som typisk gir systemiske symptomer med daglige feberepisoder, ofte ledsaget av frostanfall og nattesvette. Muskel- og leddsmerter er også vanlig. In vitro-studier indikerer at vaskulære endotelceller er mottakelige for infeksjon og derfor trolig kan utgjøre et reservoar for kronisk infeksjon (4). Det er observert høy forekomst av vaskulære komplikasjoner (5-7.). I et materiale fra Sverige med 40 pasienter, hvorav zo var immunkompromitterte, fant man vaskulære hendelser hos 24 (6o \%) av pasientene (ㅁ). Venøse komplikasjoner som tromboflebitt (11 tilfeller), dyp venetrombose (10 tilfeller) og lungeembolisme (4 tilfeller) var hyppigst. Transitorisk iskemisk attakk (TIA) ble observert hos 2 pasienter, og vaskulitt ble observert hos 3 immunfriske pasienter. Til tross for langvarige, daglige symptomer, og selv om hun ikke mottok noen antitrombotisk behandling, forelå det hos vår pasient ingen tegn til tromboemboliske hendelser.

En høy andel av pasientene i publiserte kasuistikker har vært immunsvekkede, og immunsuppresjon antas å disponere for persisterende, symptomatisk neoehrlichiose $(5, \underline{8})$. Splenektomerte pasienter og pasienter under behandling med rituksimab synes å være spesielt utsatt (9.). Immunfriske kan imidlertid også utvikle sykdom (므).

Candidatus Neoehrlichia mikurensis har stor utbredelse i flåttpopulasjoner i Europa og Asia (9.). I Norge er bakterien påvist hos flått i hele utbredelsesområdet, med geografiske

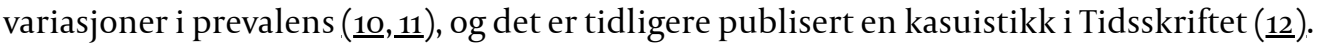
Trolig er sykdommen underdiagnostisert. Quarsten og medarbeidere (13) unders $\emptyset$ kte 70 pasienter i Agder-fylkene med symptomer etter flåttbitt, hvorav 65 hadde utslett diagnostisert som erythema migrans. PCR-analyse av EDTA-fullblod var positiv for Candidatus Neoehrlichia mikurensis hos 7 av 70 og for Borrelia burgdorferi sensu lato hos 3 av 70.

Bakterien påvises ved PCR-analyse av EDTA-fullblod, som i Norge utføres ved Mikrobiologisk avdeling ved Sørlandet sykehus. I tillegg til Candidatus Neoehrlichia mikurensis undersøkes prøven for Anaplasma phagocytophilum, Borrelia miyamotoi og Rickettsia spp. Behandlingen består av doksysyklin $100 \mathrm{mg} \times 2$ per os i tre uker. Til pasienter med straksallergi mot doksysyklin kan rifampicin $300 \mathrm{mg} \times 2$ per os forsøkes (9.), men erfaringsgrunnlaget er betydelig svakere. Doksysyklin er også behandlingen mot de øvrige flåttbårne bakteriene.

Man bør tenke på og undersøke for Anaplasmataceae-bakterier som Candidatus Neoehrlichia mikurensis ved uavklarte febertilstander og ved «atypiske» vaskulære og tromboemboliske hendelser med opplysninger om flåttbitt eller opphold i områder med flått, særlig hos pasienter med kjent immunsvekkelse. Likeledes er dette en aktuell differensialdiagnose ved «klinisk» erythema migrans, spesielt ved samtidig feber eller manglende respons på fenoksymetylpenicillin eller amoksicillin.

Med nattesvette og vekttap som eneste symptomer i cirka seks måneder hadde vår pasient et uvanlig forløp for en infeksjonssykdom. I ettertid ser vi at det også i denne fasen forelå biokjemiske tegn som kunne tale for en inflammatorisk tilstand, men fravær av feber gjorde at infeksjonsmedisinske differensialdiagnoser først ble vurdert sent $\mathrm{i}$ utredningsforløpet. Sykehistorien illustrerer derfor betydningen av en tverrfaglig tilnærming til pasienter med uavklart diagnose. 
Pasienten har gitt samtykke til at artikkelen blir publisert.

Artikkelen er fagfellevurdert.

\section{LITTERATUR}

1. Fehr JS, Bloemberg GV, Ritter C et al. Septicemia caused by tick-borne bacterial pathogen Candidatus Neoehrlichia mikurensis. Emerg Infect Dis 2010; 16: 1127-9. [PubMed][CrossRef]

2. Welinder-Olsson C, Kjellin E, Vaht K et al. First case of human "Candidatus Neoehrlichia mikurensis" infection in a febrile patient with chronic lymphocytic leukemia. J Clin Microbiol 2010; 48:1956-9. [PubMed][CrossRef]

3. von Loewenich FD, Geissdörfer W, Disqué C et al. Detection of "Candidatus Neoehrlichia mikurensis" in two patients with severe febrile illnesses: evidence for a European sequence variant. J Clin Microbiol 2010; 48: 2630-5. [PubMed][CrossRef]

4. Wass L, Grankvist A, Bell-Sakyi L et al. Cultivation of the causative agent of human neoehrlichiosis from clinical isolates identifies vascular endothelium as a target of infection. Emerg Microbes Infect 2019; 8: 413-25. [PubMed][CrossRef]

5. Grankvist A, Andersson PO, Mattsson M et al. Infections with the tick-borne bacterium "Candidatus Neoehrlichia mikurensis" mimic noninfectious conditions in patients with B cell malignancies or autoimmune diseases. Clin Infect Dis 2014; 58: 1716-22. [PubMed][CrossRef]

6. Höper L, Skoog E, Stenson M et al. Vasculitis due to Candidatus Neoehrlichia mikurensis: a cohort study of 40 Swedish patients. Clin Infect Dis 2021; 73: e2372-8. [PubMed][CrossRef]

7. Portillo A, Santibáñez P, Palomar AM et al. 'Candidatus Neoehrlichia mikurensis' in Europe. New Microbes New Infect 2018; 22:30-6. [PubMed][CrossRef]

8. Quarsten H, Salte T, Lorentzen AR et al. Tick-borne pathogens detected in the blood of immunosuppressed Norwegian patients living in a tick-endemic area. Clin Infect Dis 2021; 73: e236471. [PubMed][CrossRef]

9. Wennerås C. Infections with the tick-borne bacterium Candidatus Neoehrlichia mikurensis. Clin Microbiol Infect 2015; 21: 621-30. [PubMed][CrossRef]

10. Jenkins A, Kristiansen BE. Neoehrlichia - nok en flåttbakterie. Tidsskr Nor Legeforen 2013; 133: 1058-9. [PubMed][CrossRef]

11. Jenkins A, Raasok C, Pedersen BN et al. Detection of Candidatus Neoehrlichia mikurensis in Norway up to the northern limit of Ixodes ricinus distribution using a novel real time PCR test targeting the groEL gene. BMC Microbiol 2019;19: 199. [PubMed][CrossRef]

12. Frivik JO, Noraas S, Grankvist A et al. En mann i 6o-årene fra Sørlandet med intermitterende feber. Tidsskr Nor Legeforen 2017; 137: 23-4. [PubMed]

13. Quarsten H, Grankvist A, Høyvoll L et al. Candidatus Neoehrlichia mikurensis and Borrelia burgdorferi sensu lato detected in the blood of Norwegian patients with erythema migrans. Ticks Tick Borne Dis 2017; 8: 715-20. [PubMed][CrossRef]

Publisert: 22. november 2021. Tidsskr Nor Legeforen. DOI: 10.4045/tidsskr.21.0332

Mottatt 22.4.2021, første revisjon innsendt 23.6.2021, godkjent 23.8.2021.

Publisert under åpen tilgang CC BY-ND. Lastet ned fra tidsskriftet.no 26. april 2023. 